\title{
Data report: calcareous nannofossil assemblages at IODP Expedition 303 Site U1308 during the last 550,000 years ${ }^{1}$
}

\author{
Shun Chiyonobu, ${ }^{2}$ Hiroko Kageyama, ${ }^{3}$ and Tokiyuki Sato ${ }^{3}$
}

\begin{abstract}
Chapter contents

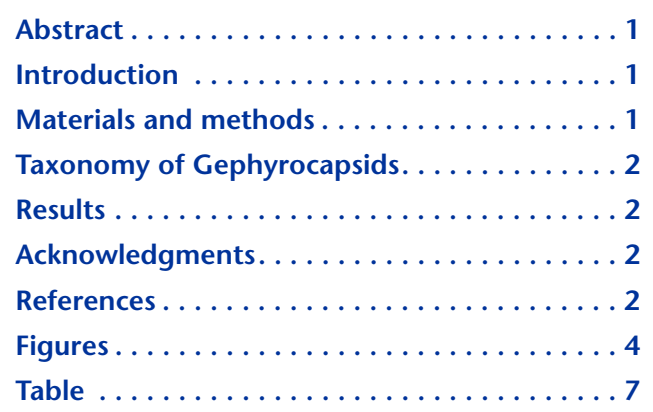

${ }^{1}$ Chiyonobu, S., Kageyama, H., and Sato, T., 2010. Data report: calcareous nannofossil assemblages at IODP Expedition 303 Site U1308 during the last 550,000 years. In Channell, J.E.T., Kanamatsu, T., Sato, T., Stein, R., Alvarez Zarikian, C.A., Malone, M.J., and the Expedition 303/306 Scientists, Proc. IODP, 303/306: College Station, TX (Integrated Ocean Drilling Program Management International, Inc.). doi:10.2204/iodp.proc.303306.211.2010 ${ }^{2}$ Institute of Geology and Paleontology, Graduate School of Science, Tohoku University, AramakiAoba, Sendai 980-8578, Japan.

chiyonobu@mail.tains.tohoku.ac.jp ${ }^{3}$ Institute of Applied Earth Sciences, Faculty of Engineering and Resource Science, Akita University, Akita 010-8502, Japan.

\begin{abstract}
Late Quaternary calcareous nannofossil assemblages at Integrated Ocean Drilling Program Site U1308, located in the North Atlantic Ocean, were analyzed in sediments covering the last 550,000 y. The uppermost Quaternary sediments at this site contain abundant nannofossils, and their assemblages are characterized by high species diversity. Nannofossil assemblages are characterized by abundant small specimens $(<4 \mu \mathrm{m})$ of Gephyrocapsa throughout the sequence. Conversely, the upper part of the sequence is dominated by Coccolithus pelagicus, Calcidiscus leptoporus, and Emiliania huxleyi.
\end{abstract}

\section{Introduction}

Coccolithophores are a major group of marine, unicellular phytoplankton, composed of calcareous plates (coccoliths) that form an important part of the fine-grained deep-sea sedimentary record and therefore are extensively used in biostratigraphic, paleoecologic, and paleoceanographic studies (e.g., Sato et al., 1999). In addition, coccolithophores have recently gained increased attention, as they make an important contribution to oceanic primary production. Their biogeographical distribution appears to be especially related to water temperature and nutrient concentration, as does their preservation (e.g., Okada and Honjo, 1973). In addition, shifts in species composition observed in several sediment cores have been attributed to changes in upwelling and seasurface current systems.

In the present report, we present coccolith data over the last 550,000 y from Integrated Ocean Drilling Program (IODP) Site U1308 in the North Atlantic Ocean. This time interval contains a globally expressed climatic change, the Mid-Brunhes Event (MBE), centered at $\sim 400 \mathrm{ka}$ and likely forced by orbital eccentricity (Jansen et al., 1986; Pisias and Rea, 1988; Crowley and North, 1991).

\section{Materials and methods}

The uppermost Quaternary samples used in this study were collected from Site U1308. Site U1308 is a reoccupation of Deep Sea Drilling Project (DSDP) Leg 94 Site 609 and is located at $49^{\circ} 52.666^{\prime} \mathrm{N}, 24^{\circ} 14.287^{\prime} \mathrm{W}$ (Fig. F1). The uppermost Quaternary 
sediments at this site are composed mainly of nannofossil and foraminifer ooze. Samples were analyzed at $\sim 10-20 \mathrm{~cm}$ intervals.

All samples were processed as follows:

1. Powdered sample $(0.04 \mathrm{~g})$ was put into a small beaker, and $50 \mathrm{~mL}$ of water was added to make a suspension.

2. Suspension medium $(0.5 \mathrm{~mL})$ was placed on a coverslip $(18 \mathrm{~mm} \times 18 \mathrm{~mm})$ with a pipette.

3. The coverslip was dried on a hotplate.

4. Samples were mounted on a microslide using Norland optical adhesive.

Microslides were observed under a binocular polarizing microscope at $1500 \times$ magnification. A total of 200 nannofossil specimens, excluding Florisphaera profunda, were counted at random to determine their relative frequencies.

Preservation quality was assessed using five categories: very good and good for little or no evidence of dissolution and/or overgrowth, moderate for minor dissolution or crystal overgrowth, and poor and very poor for strong dissolution or crystal overgrowth, in which case many specimens are unidentifiable (Fig. F2). Reworked calcareous nannofossils were not documented in any of the samples.

\section{Taxonomy of Gephyrocapsids}

Most of the species identified in this study belong to the family Noelaerhabdaceae (reticulofenestrids including the genera Emiliania, Pseudoemiliania, Reticulofenestra, and Gephyrocapsa) (Thierstein et al., 1977; Raffi et al., 1993; Wei, 1993; Flores et al., 1999; Flores et al., 2000). Gephyrocapsid taxonomy is based on reports by Raffi et al. (1993), Flores et al. (2000), Takahashi and Okada (2000), and Baumann and Freitag (2004). The genus Gephyrocapsa was first divided into Gephyrocapsa caribbeanica, Gephyrocapsa oceanica, Gephyrocapsa muellerae, and other forms, and the latter were divided into two taxonomic groups based on coccolith length (i.e., small [2.5-3.5 $\mu \mathrm{m}]$ and very small $[<2.5 \mu \mathrm{m}])$. Several authors found that the angle between the lob axis and the bridge of Gephyrocapsa was related to temperature (e.g., Bollmann, 1997). We also classified very small Gephyrocapsa spp. into three groups: $>45^{\circ}$ (Gephyrocapsa spp. [small] and G. oceanica), $0^{\circ}-25^{\circ}$ (G. muellerae), and $0^{\circ}-45^{\circ}$ (G. caribbeanica), which indicate warm, cold, and intermediate temperature, respectively. In particular, the very small forms of Gephyrocapsa spp. and Reticulofenestra spp. are mainly represented by specimens smaller than $2.5 \mu \mathrm{m}$ (Table T1).

\section{Results}

The age model in this study is established primarily on the oxygen isotope stratigraphy and some wellknown calcareous nannofossil biostratigraphic events for Site U1308 based on Sato et al.

Fourteen genera and 15 species were recognized at Site U1308. Almost all samples contain well-preserved nannofossils throughout the sequence except in the ice-rafted detritus (IRD) intervals where some samples contain poorly preserved nannofossils or are barren (Fig. F2). Badly dissolved specimens characterize these intervals.

Genus Gephyrocapsa, which includes Gephyrocapsa aperta, Gephyrocapsa sinousa, G. caribbeanica, G. muellerae, and G. oceanica, is dominant throughout the sequence (Fig. F3). The upper part of the sequence is characterized by abundant occurrences of Calcidiscus leptoporus, Coccolithus pelagicus, and Emiliania huxleyi. Gephyrocapsa parallela, Helicosphaera carteri, small specimens $(<4 \mu \mathrm{m})$ of Reticulofenestra, and Umbilicosphaera sibogae are present throughout the sequence; however, these taxa are low in abundance (a few percent) in the examined interval. Phontosphaera spp., Syracosphaera pulchra, and Umbellosphaera spp. exhibit sporadic occurrences throughout the sequence (Fig. F3). F. profunda is nearly absent throughout the sequence at Site U1308.

\section{Acknowledgments}

Samples for this study were provided by the Integrated Ocean Drilling Program. We are grateful to many of the scientific staff on board the R/V JOIDES Resolution. We wish to express our gratitude to Professor Motoyoshi Oda of Tohoku University for his advice, helpful suggestions, and critical reading of this manuscript. We are also grateful to Associate Professor Yasufumi Iryu for encouragement in the completion of this work and for valuable suggestions on paleoceanography.

\section{References}

Baumann, K.-H., and Freitag, T., 2004. Pleistocene fluctuations in the northern Benguela Current system as revealed by coccolith assemblages. Mar. Micropaleontol., 52(1-4):195-215. doi:10.1016/j.marmi-

cro.2004.04.011

Bollmann, J., 1997. Morphology and biogeography of Gephyrocapsa coccoliths in Holocene sediments. Mar. Micropaleontol., 29(3-4):319-350. doi:10.1016/

S0377-8398(96)00028-X 
Crowley, T.J., and North, G.R., 1991. Paleoclimatology: Oxford Monographs on Geology and Geophysics: New York (Oxford Univ. Press).

Flores, J.-A., Gersonde, R., and Sierro, F.J., 1999. Pleistocene fluctuations in the Agulhas current retroflection based on the calcareous plankton record. Mar. Micropaleontol., 37(1):1-22. doi:10.1016/S0377-8398(99)00012-2

Flores, J.-A., Gersonde, R., Sierro, F.J., and Niebler, H.-S., 2000. Southern Ocean Pleistocene calcareous nannofossil events: calibration with the isotope and geomagnetic stratigraphies. Mar. Micropaleontol., 40(4):377-402. doi:10.1016/S0377-8398(00)00047-5

Jansen, J.H.F., Kuijpers, A., and Troelstra, S.R., 1986. A midBrunhes climatic event: long-term changes in global atmosphere and ocean circulation. Science, 232(4750):619-622. doi:10.1126/science.232.4750.619

Okada, H., and Honjo, S., 1973. The distribution of oceanic coccolithophorids in the Pacific. Deep-Sea Res. Part A, 20:355-374.

Pisias, N.G., and Rea, D.K., 1988. Late Pleistocene paleoclimatology of the central equatorial Pacific: sea surface response to the southeast trade winds. Paleoceanography, 3(1):21-37. doi:10.1029/PA003i001p00021

Raffi, I., Backman, J., Rio, D., and Shackleton, N.J., 1993. Plio-Pleistocene nannofossil biostratigraphy and calibration to oxygen isotope stratigraphies from Deep Sea
Drilling Project Site 607 and Ocean Drilling Program Site 677. Paleoceanography, 8(3):387-408. doi:10.1029/ 93PA00755

Sato, T., Kameo, K., and Mita, I., 1999. Validity of the latest Cenozoic calcareous nannofossil datums and its application to the tephrochronology. Earth Sci., 53(4):265274. [in Japanese]

Takahashi, K., and Okada, H., 2000. The paleocenography for the last 30,000 years in the southeastern Indian Ocean by means of calcareous nannofossils. Mar. Micropaleontol., 40(1-2):83-103. doi:10.1016/S03778398(00)00033-5

Thierstein, H.R., Geitzenauer, K.R., Molfino, B., and Shackleton, N.J., 1977. Global synchroneity of late Quaternary coccolith datum levels validation by oxygen isotopes. Geology, 5(7):400-404. doi:10.1130/ 0091-7613(1977)5<400:GSOLQC>2.0.CO;2

Wei, W., 1993. Calibration of upper Pliocene-lower Pleistocene nannofossil events with oxygen isotope stratigraphy. Paleoceanography, 8(1):85-99. doi:10.1029/ 92PA02504

Initial receipt: 10 October 2008

Acceptance: 30 March 2010

Publication: 28 May 2010

MS 303306-211 
Figure F1. Area of study and location of the Site U1308. NAC = North Atlantic Current, AZC = Azores Current, EGC $=$ East Greenland Current, NC = Norwegian Current, GS = Gulf Stream, CC $=$ Canary Current.

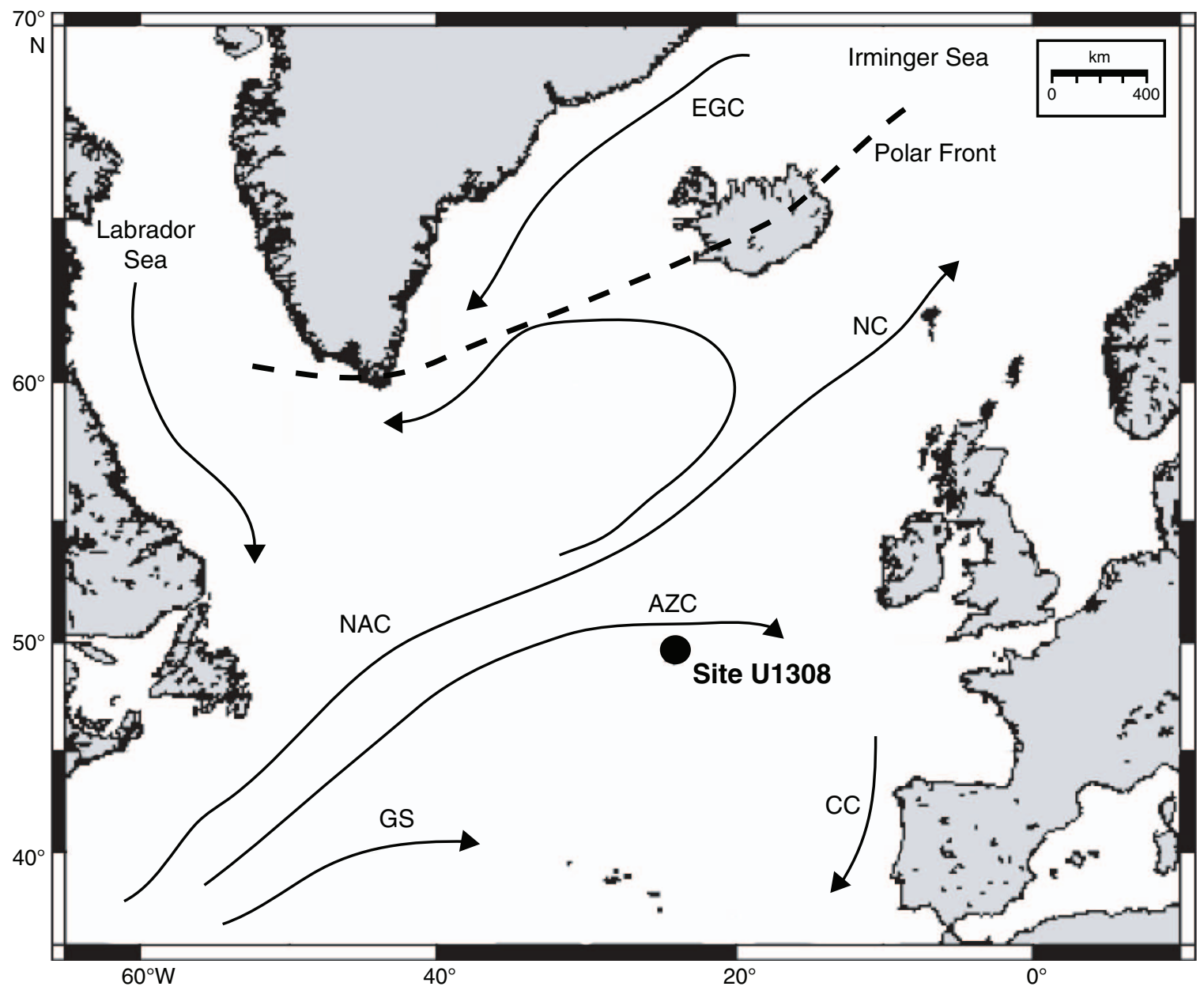


Figure F2. Downhole preservation of calcareous nannofossils, Site U1308.

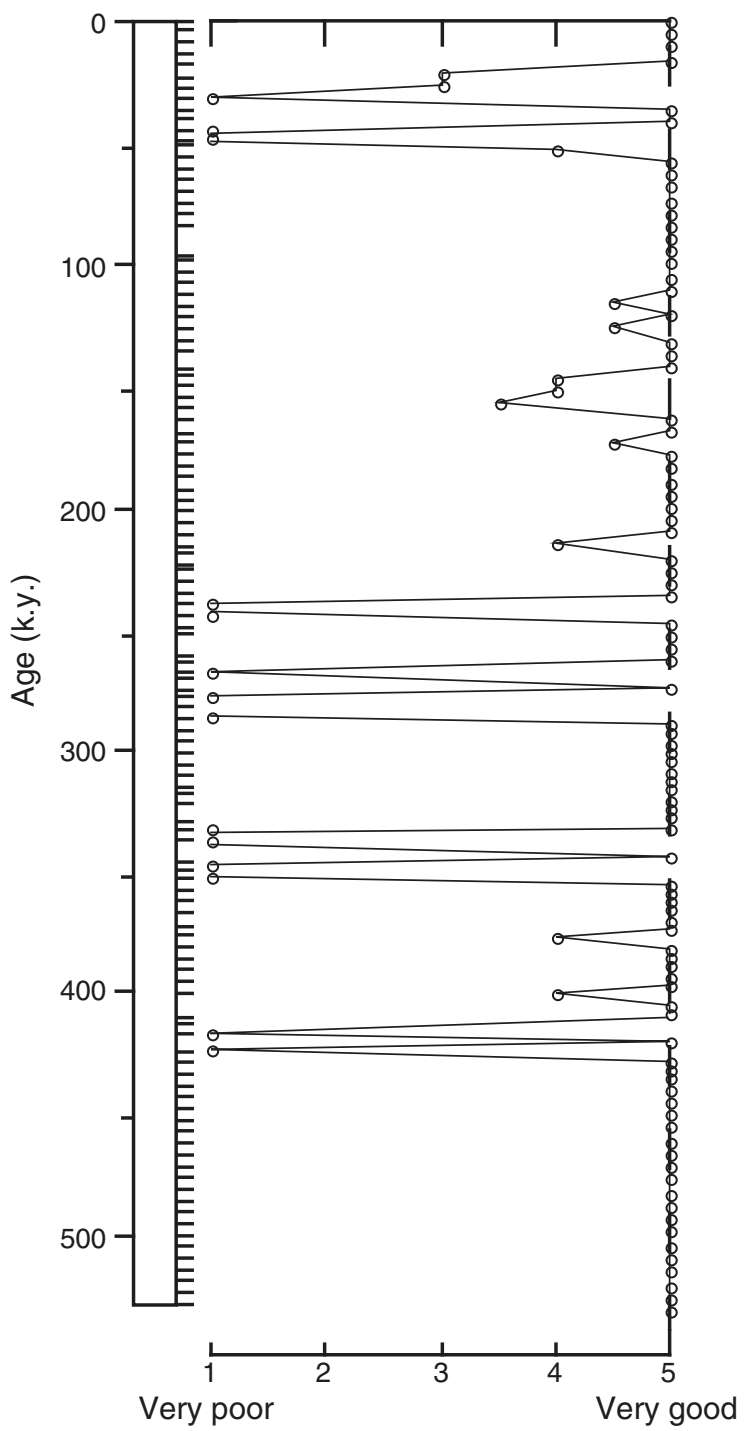


Figure F3. Stratigraphic distribution of calcareous nannofossils, Site U1308. Includes calcareous nannofossil datums Emiliania huxleyi (first occurrence $=265 \mathrm{ka}$ ) and Pseudoemiliania lacunosa $($ last occurrence $=451 \mathrm{ka}$ ) from Sato et al.

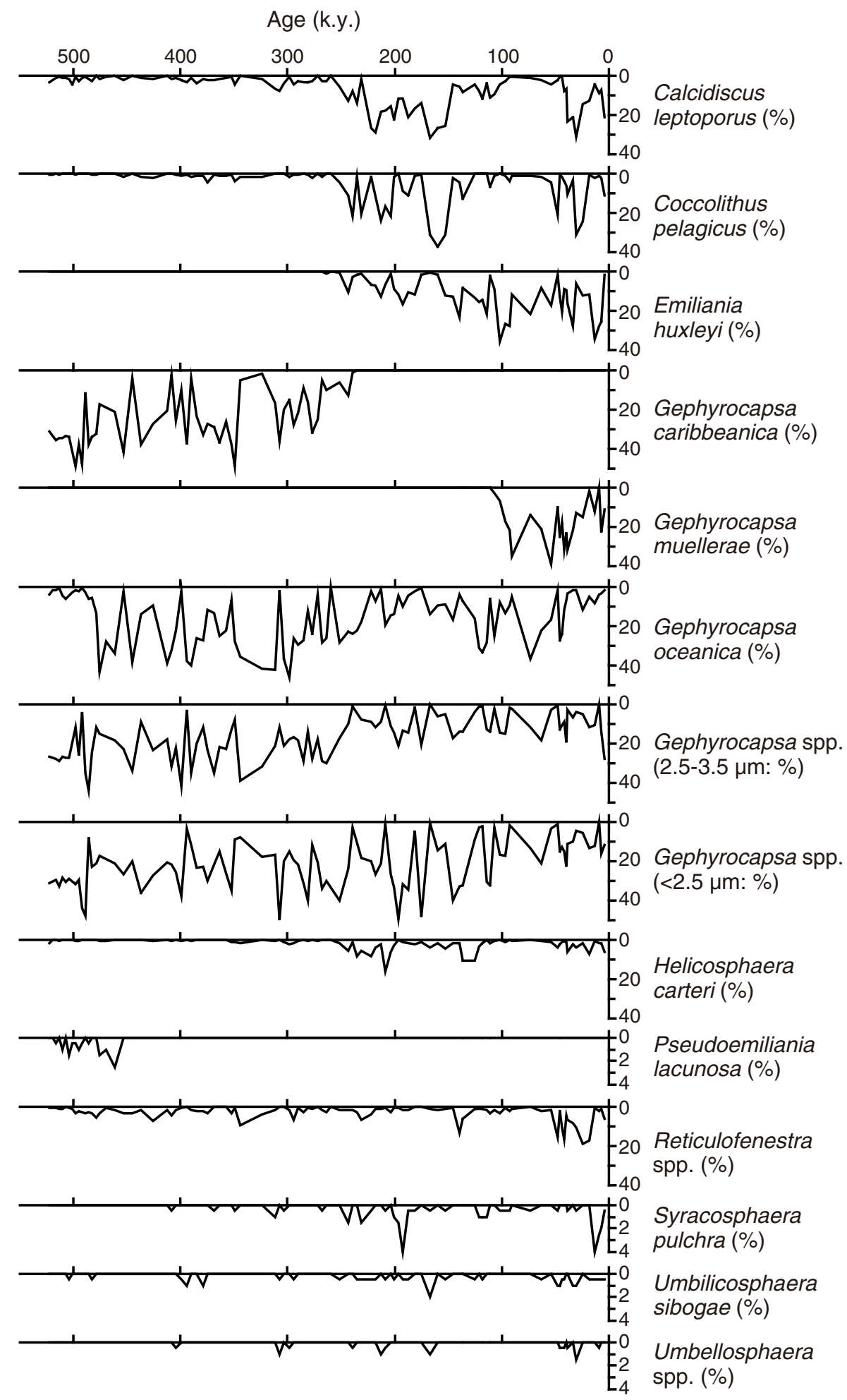


Table T1. Terminology for Gephyrocapsa spp. (See table note.)

\begin{tabular}{|c|c|c|c|c|c|}
\hline $\begin{array}{l}\text { This study } \\
\text { Coccolith size }(\mu \mathrm{m}) \\
\text { Bridge angle }\left(^{\circ}\right) \\
\end{array}$ & $\begin{array}{l}\text { Gephyrocapsa spp. (very small) } \\
<2.5 \\
0-90\end{array}$ & $\begin{array}{l}\text { Gephyrocapsa spp. (small) } \\
2.5-3.5 \\
>45\end{array}$ & $\begin{array}{l}\text { Gephyrocapsa muellerae } \\
2.5-4 \\
0-25\end{array}$ & $\begin{array}{l}\text { Gephyrocapsa caribbeanica } \\
>3.5 \\
0-45\end{array}$ & $\begin{array}{l}\text { Gephyrocapsa oceanica } \\
>3.5 \\
>45\end{array}$ \\
\hline \multicolumn{6}{|l|}{ Other authors } \\
\hline Bollmann (1997) & Gephyrocapsa minute & Gephyrocapsa equatorial & Gephyrocapsa cold & $\begin{array}{l}\text { Gephyrocapsa oligotrophic/ } \\
\text { Gephyrocapsa transitional }\end{array}$ & $\begin{array}{l}\text { Gephyrocapsa large/Gephyrocapsa } \\
\text { equatorial }\end{array}$ \\
\hline Flores et al. (2000) & Small Gephyrocapsa & Gephyrocapsa oceanica & Gephyrocapsa muellerae & Gephyrocapsa caribbeanica & Gephyrocapsa oceanica \\
\hline Takahashi and Okada (2000) & Small Gephyrocapsa & $\begin{array}{l}\text { Medium Gephyrocapsa; } \\
\text { high/intermediate bridge angle (warm) }\end{array}$ & $\begin{array}{l}\text { Medium Gephyrocapsa; } \\
\text { low bridge angle (cold) }\end{array}$ & Gephyrocapsa caribbeanica & $\begin{array}{l}\text { Medium/Large Gephyrocapsa; } \\
\text { high/intermediate bridge angle } \\
\text { (warm) }\end{array}$ \\
\hline Bauman and Freitag (2004) & $\begin{array}{l}\text { Gephyrocapsa ericsonii/ } \\
\text { Gephyrocapsa aperta }\end{array}$ & $\begin{array}{l}\text { Gephyrocapsa muellerae/ } \\
\text { Gephyrocapsa caribbeanica }\end{array}$ & Gephyrocapsa muellerae & Gephyrocapsa caribbeanica & Gephyrocapsa oceanica \\
\hline
\end{tabular}

Note: Other authors' equivalents mainly adopted from Baumann and Freitag (2004). 